\title{
Pocket Book Based on Comic to Improve Conceptual Understanding of Child Sex Abuse (CSA): A Case Study of Elementary School
}

\author{
Winarto \\ Peradaban University, Faculty of Education, Indonesia,wiwin16@gmail.com \\ Ujang Khiyarusoleh \\ Peradaban University, Faculty of Education, Indonesia, ujang606bk@gmail.com \\ Aqib Ardiyansyah \\ Peradaban University, Faculty of Education, Indonesia, ardi_atsauroh@yahoo.co.id \\ Insih Wilujeng \\ Yogyakarta State University, Master Of Science Education, Indonesia, \\ insihuny@yahoo.co.id

\section{Sukardiyono} \\ Yogyakarta State University, Master Of Science Education, Indonesia, \\ sukarfisuny@yahoo.co.id
}

The purposes of this research were 1) to produce a pocket book based on comic to be called BUSAPAKSA; (2) determine the appropriateness and quality of pocket book based on comic that had been developed; and (3) to describe the improvement in learning conceptual understanding after using pocket book. The present research employs a Research and Development (R\&D) method by developing a model proposed by Borg and Gall (1983). The product was validated by a psychologist, an instructional media expert, and elementary teachers. The product was performed through preliminary, limited, and broader test. The boarder testing used one shot case study. The research subjects were 360 the fifth grade students elementary school students in Brebes, Tegal, and Banyumas regency and Tegal city. The data collection was conducted by using a questionnaire and conceptual understanding test. Results of the study indicated: (1) BUSAPAKSA was a pocket book based on comic that could be used for learning; (2) BUSAPAKSA was quite viable as learning media and of very good quality; (3) The learning conducted using BUSAPAKSA could improve the students' understanding. The results showed that the students' average gain score was classified into medium category.

Keywords: pocket book, understanding, students, elementary school, case study

Citation: Winarto, Khiyarusoleh, U., Ardiyansyah, A., Wilujeng, I., \& Sukardiyono. (2018). Pocket Book Based on Comic to Improve Conceptual Understanding of Child Sex Abuse (CSA): A Case Study of Elementary School. International Journal of Instruction, 11(4), 889-900. https://doi.org/10.12973/iji.2018.11456a 


\section{INTRODUCTION}

In Indonesia, CSA has been continuously increasing from time to time. Orange and Brodwin (2005) state that CSA is classified into a coercive, threatening or deceitful crime on children's sexual activities, including staring, touching, penetrating (pressing), sexual violating and rapping. Al haq, Raharjo, and Wibowo (2015) explain that Indonesia children are highly vulnerable to CSA since they do not understand their surrounding environment and are easily influenced that supervision and protection from various parties should be well provided and paid high attention. Dube, Anda, Whitfield, Brown, Felitti, Dong, and Giles (2005) state that CSA victims have experienced a number of similar problems, including continuous physical and psychological trauma, life spirit lost, disliking their opposite sex and tendency to make a revenge. Paramastri, Prawitasari, Prabandari and Ekowarni (2011) believe that sexual education socialization is greatly necessary for the elementary school students and should be followed up by the school principals.

Pramono (2014) states that sexual education is still considered taboo to be discussed in Indonesia, especially in school environment. Brown (2013) states that sexual education taught by the parents is not only information about sex, but also a form of self-defense from those who have bad intention to children. Paramastri, Supriyanti, and Priyanto (2011) states an early prevention program of CSA is highly needed to be realized and it should use visual media, such as picture, comic, as well as audio-visual media. According to the results of observations in the field, the problems faced by the elementary school teachers are due to the inexistence of learning media to implement sex education.Moreover, favorite learning media of elementary school students are pictorial books.

Davis (1997) explains that a book containing illustrated stories may become an interesting educational medium to encourage the students' learning spirit and is easily found in newspapers and bookstores, containing stories about daily life, and provides various learning styles. Mitchell (2003) states that picture storybooks are books in which the picture and text are tightly intertwined. Neither the pictures nor the words are self sufficient; they need each other to tell the story". According to McCould (2011), comic is a kind of visual communication media which is effective to deliver information in a popular and easy way. This is due to the fact that comic combines both pictures and words connected in a story plot which makes the information understood more easily.

The usefulness of comic books, according to the explanations presented in the case here, is as solution to limitations in learning in media to implement sex education. Therefore, some researches need to be made with the purpose of developing a BUSAPAKSA based on comic focusing on materials of CSA to improve conceptual understanding of CSA. Therefore, the objective of the research concerned here was to result in BUSAPAKSA based on comic materials which was flexible and interactive, with high levels of appropriateness and quality, and able to improve conceptual understanding. 


\section{LITERATURE REVIEW}

Early sexual education is an effort that the parents and teachers may perform to protect children from the dangers of sexual abuse. Lazarini (2013) opinies that several ways to prevent children from the CSA are introducing parts of reproductive organs which other people may not touch and providing information about the perpetrators and vulnerable places regarding to children sexual abuse. Parasmatri, Supriyati, and Priyatno (2010) believe that early sexual education aims at assisting the children dealing with their biological changes, avoiding false understanding and preventing from CSA. Sexual education is important as an effort preventing form CSA. It needs learning media to help the students obtain information about CSA, one of those media is book.

Books are printed media used by most Elementary School students. Sulistyani, Jamzuri, and Rahardjo, (2013) states that pocket book is used as one supporting instrument to deliver information about one-way learning materials and others to improve the students' potentials to become self-learners. Davis (1997) explains that a book containing illustrated stories may become an interesting educational medium to encourage the students' learning spirit and is easily found in newspapers and bookstores, containing stories about daily life, and provides various learning styles. Pramastri, Supriyanti, and Priyanto (2010) opine that the implementation of sexual education at schools trough books contain the pictures of part of body which are arranged based on a plot of story. Nurhidayati and Pratiwi (2013) mention that implanting values and morals to the elementary school children with a storytelling approach may be conducted in various ways, involving the contents of folklore, educational story, real story, and others adapted from the Indonesian stories. The utilization of symbols, colors, and font sizes is considered good by the evaluator. Font size, image sharpness, and color may ease the students to read.

\section{Improvement in Students' Conceptual Understanding}

Conceptual understanding is a process of constructing meaning of an object or event (Arends, 2012). Santrock (2008) states that conceptual understanding is one key learning aspect which may become the benchmark of successful learning objectives. One important teaching objective is to help the students understand the main concept of a subject, not only remembering the separated facts. Conceptual understanding may develop when the teachers may help the students appropriately and interestingly explore various topics obtained from a concept.

Jatmikowati, Wind, and Ernawati (2015) state that teachers help the student understand CSA needed to be given by the teachers and help the students recognize and keep all parts of body including sexual and reproduction organs. The teachers give right understanding about family, its aim, the responsibility of each member, as well as about faith, love and respect.

\section{METHOD}

The research was of the type known as R\&D (Research \& Development). The type was chosen because the objective was to develop a learning media product acquiring fine levels of appropriateness and quality through a process of validation and field testing 
activity.The products resulted in this research were a comic-based pocket book. This book was packaged by using story approach which contains CSA materials.

\section{Procedure of Development}

The development procedure in this study included a modification of Borg and Gall (1983) model and the learning design model of Dick and Carey. (2001). The stages consisted of, among others, activities of analysis, design, and development, validation, and product evaluation. A need analysis was done through observations of and interviews with teachers and students. The objective of the need analysis activity was to obtain data that would be useful for developing the BUSAPAKSA in accordance for learning CSA materilas. After the need analysis activity, then the stage of design and development was conducted. The result of design and development was then evaluated in terms of its appropriateness and quality through the stage of product validation. The validation was done by a psychologist and in the learning media. Besides experts'validation, evaluation was also done by the researcher's colleagues and teachers of elementary school. Then the validation result was analyzed to get information of the quality and to come up with suggestions for product improvement.The product utilization test was performed through preliminary, limited, and broader test. The preliminary trial was conducted on fifteen students of Islamic Elementary School Class VB of T. Huda Bumiayu intended to obtain information facilitation to understand the story, image sharpness, font size and useful of BUSAPAKSA. A limited trial is conducted on twenty eight students Grade VA of Islamic Elementary School T. Hudda in order to obtain information on learning processes.

Broader product testing was conducted on 360 students from twelve elementary schools in Brebes, Tegal, and Banyumas regency as well as those in Tegal city. The broader product test was intended to obtain more information on improving the students' understanding on the concept of children CSA.

\section{Data Collection Instrument}

The research data were obtained using questionnaire and a test of conceptual understanding. The questionnaire was used in the validation performed by the psychologists, learning media experts, elementary school teachers, and students. The product was administered to students at pre-test time, namely, when the students had not yet used BUSAPAKSA, and at post-test time, namely, when they had already used it.

\section{Media Assessment Instrument}

The media assessment instrument in this research was a questionnaire. Questionnaires were used to find out about the validity of BUSAPAKSA and based on expert judgments (media experts and material experts). There were 27 questions in this questionnaire. The design of media assessment questionnaire was developed based on the theory of assessment criteria of media learning according to some experts who have been described in the study of theory. Questionnaire was validation developed in the form of a grid that contained aspects and indicators of data characteristics required in this study. Questionnaire BUSAPASKA includes two aspects of media and materials. 
Assessment was developed using a likert scale of 1-4 Likert scale that had been modified by omitting the middle value of a scale of 1-5 in order to avoid ambiguity during the analysis. Questionnaire BUSAPASKA content validity was determined by expert judgment.

\section{Conceptual understanding Instrument}

The students' conceptual understanding of CSA was measured trough test. The contents and construction of tests had been validated by instrument validators. Empirical validation was analyzed using SPSS program. Ten test items were valid. R count> $\mathrm{R}$ table at $5 \%$ significance level for the number of respondents 30 students.

\section{Technique of Data Analysis}

The research data were analyzed by descriptive and inferential analyses. The descriptive analysis was used to analyze the data of product validation and improvement conceptual understanding of CSA. The inferential analysis was used to analyze any improved understanding as a whole. The analysis of data resulting from BUSAPAKSA by the evaluators was converted and classified into five categories. Azwar (2011) makes a classification with comparison to the ideal average score $\left(X_{i}\right)$ and the ideal standard deviation score (SBi) as basis. The categorization of product assessment is presented in Table 1.

Table 1

Product assessment categorization

\begin{tabular}{lll}
\hline No & Interval Skor & Category \\
\hline 1 & $\mathrm{X}>\mathrm{Xi}+1,5 \mathrm{Sbi}$ & Very Good \\
2 & $\mathrm{Xi}+\mathrm{Sbi}<\mathrm{X}<\mathrm{Xi}+1,5 \mathrm{Sbi}$ & Good \\
3 & $\mathrm{Xi}-0,5 \mathrm{Sbi}<\mathrm{X}<\mathrm{Xi}+1,5 \mathrm{Sbi}$ & Enough \\
4 & $\mathrm{Xi}-1,5 \mathrm{Sbi}<\mathrm{X}<\mathrm{Xi}-0,5 \mathrm{Sbi}$ & Bad \\
5 & $\mathrm{X}<\mathrm{Xi}-1,5 \mathrm{Sbi}$ & Very Bad \\
\hline
\end{tabular}

The analysis of the data obtained from the questionnaire was done by converting the qualitative data into quantitative data. The data of the conceptual understanding test resulted from CSA conceptual comprehension test. The scores for conceptual understanding were calculated with the data from pretest and posttest times as basis. Any improvement conceptual understanding was descriptively obtained with the normalized gain score as basis. The data used to calculate the gain score were the ones from beginning and end times. Pre-test and post-test data were calculated as score gain by Hake (1998). The formula calculated the gain score using equation one.

$$
(g)=\frac{\$ f-\$ i}{100-\$ i}
$$

With $S f$ being the post-test value, $S i$ is the pre-test value, and $g$ is the gain of the score. Acquired gain is individualized for each learner, and then calculated as average. The average gain value of each learner is categorized as the increase of gain score according to Hake (1998). The categorization of the gain of learners is presented in Table 2. 
Table 2

Categorization of gain scores

\begin{tabular}{lll}
\hline No & Interval & Category \\
\hline 1 & $(\mathrm{~g}) \geq 0,7$ & High \\
2 & $0,7>(\mathrm{g}>) \geq 0,3$ & Medium \\
3 & $(\mathrm{~g})<0,3$ & Low \\
\hline
\end{tabular}

\section{FINDINGS AND DISCUSSION}

\section{Analysis Study Stage}

The comic-based pocket book media were developed based on the results obtained from the stage of need analysis study. Interview results obtained from teachers revealed that sexual education had never been performed by the teachers and schools. The reason was that teachers had never received training on sexual education, there was no supporting medium, as well as the teachers and school principals had no courage to provide sexual education yet. Sexual education was still considered taboo by the students' parents/guardian parents. Pictorial books were preferred by elementary school students as favorite learning media Based on need analysis, the media of sexual education for elementary school students in the form of pictorial story book containing information about CSA were highly needed to improve the students' understanding. Early age sexual education was given the children understanding on their body condition, difference in sex and CSA Prevention.

\section{Design Product Of BUSAPAKSA.}

The developed media were well known as BUSAPAKSA (Buku Saku Pintar Anti Kekerasan Seksual/ Prevention CSA Smart Pocket Book). BUSAPAKSA was designed in three parts. The first part was called the book manual instructions which provided information how to learn themes and consisted of introductory information about the story title, material summary, and keywords. This section also aimed at helping students use BUSAPAKSA. The second part of the book was learning material contents under study. The material was organized based on characters and plots of the book. The stories were organized based on activities that the students performed in their daily life. The last part of BUSAPAKSA was smart information. Smart information was important information related to the preventive actions in the CSA. This smart information was presented at the end of each story. 
PETUNJUK PENGGUNAAN BUKU
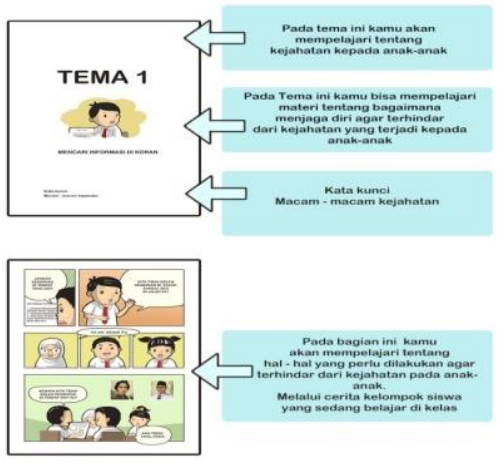

Figure 1

Learning material contents
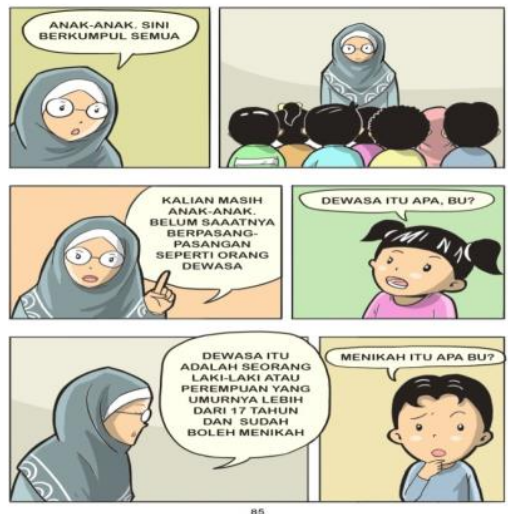

Figure 3

Smart Information

BUSAPAKSA design contained CSA material in story approach. Rahmawati (2012) says that an accurate social story strategy, which describes situations and pure comic conversation by using visual symbols, abstract conversational concept and columns which indicate emotional content, can improve the students' understanding on sexual education. BUSAPAKSA consisted of seven stories, which were as follows: (1) rrecognizing and maintaining My body parts; (2) Recognizing Family Members; (3) Computer and Internet Learning; (4) Recognizing the Police Offices;(5) Going to the Zoo; (6) Fishing in the River and (7) Being Adult Game

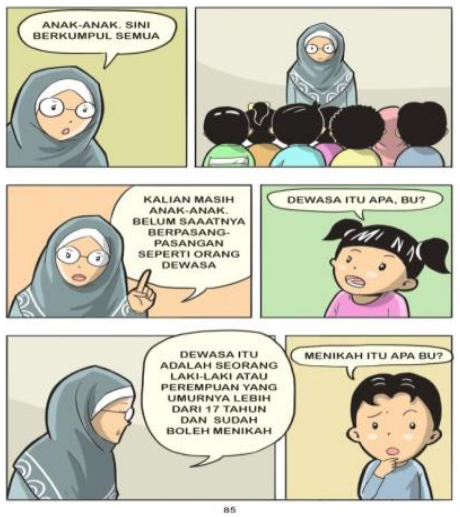

Figure 2.

The instruction to use the book 


\section{Result of BUSAPAKSA Validation}

The validation of media and materials aspect of BUSAPAKSA was done by media experts and psychologists. The results of validation could be seen in Table 3 .

Tablee 3

Product validation result

\begin{tabular}{clllll}
\hline No & Validators & $\begin{array}{l}\text { Mean Score Of Aspect } \\
\text { Learning Material }\end{array}$ & Media & $\begin{array}{l}\text { Maximum } \\
\text { Score }\end{array}$ & Category \\
\hline 1 & children psychologists & 4.4 & 4.0 & 5.0 & Very Good \\
2 & learning media experts & 4.6 & 5.0 & 5.0 & Very Good \\
3 & Teacher 1 & 4.8 & 4.4 & 5.0 & Very Good \\
4 & Teacher 2 & 4.6 & 4.5 & 5.0 & Very Good \\
5 & Teacher 3 & 4.7 & 4.6 & 5.0 & Very Good \\
6 & Teacher 4 & 3.2 & 3.1 & 5.0 & Enough \\
7 & Teacher 5 & 3.4 & 3.2 & 5.0 & Enough \\
8 & Teacher 6 & 3.7 & 4.9 & 5.0 & Very Good \\
9 & Teacher 7 & 4.5 & 4.2 & 5.0 & Very Good \\
10 & Teacher 8 & 4.6 & 4.3 & 5.0 & Very Good \\
11 & Teacher 9 & 3.8 & 3.9 & 5.0 & Very Good \\
& Average & 4.2 & 4.2 & 5.0 & Very Good \\
\hline
\end{tabular}

All aspects were categorized as very appropriate with the average obtained score of 4.2 for matterials aspect and media aspect, which was 5 of the maximum score. The validators suggested some developments as follows; (a) topic one discussing the types of sexual violence should be removed since it was not in accordance with the students' cognitive development; (b) introducing sexual education for parents should be added. In theory, sexual education may be obtained from both schools and families; (c) word choices used in packaging the stories should be reconsidered and adjusted to the students' cognitive development; (d) the presented visual comics were organized based on the factual conditions. For example, the classroom was decorated with pictures of national heroes, presidents and others.

\section{Result of Preliminary Trial.}

The preliminary trial was conducted on fifteen teen students of Islamic Elementary School Class VB of T. Huda Bumiayu. The result of preliminary trial products was classified into good category. The results of preliminary trial could be seen in Table 4 .

Table 4

Preliminary Trial Result

\begin{tabular}{lllll}
\hline No & Aspect & Mean & Max Score & Category \\
\hline 1 & Grapic & 4.5 & 5.0 & Very Good \\
2 & Learning Matterial & 3.9 & 5.0 & Very Good \\
3 & Usefull & 4.2 & 5.0 & Very Good \\
& Average & 4.2 & 5.0 & Very Good \\
\hline
\end{tabular}

Results of validation by student indicated that the BUSAPAKSA was declared valid. All aspects were categorized as very appropriate with the average obtained score of 4.2 for which was 5 of the maximum score. 


\section{Result of Limited Trial}

A limited trial was conducted on twenty eight students Grade VA of Islamic Elementary School T. Hudda. The results of the limited trial products were classified into good categories. The results of limited trial were presented in Table 5.

Table 5

Limited trial result

\begin{tabular}{lllll}
\hline No & Aspect & Mean & Max Score & Category \\
\hline 1 & Grapic & 4.2 & 5.0 & Very Good \\
2 & Learning Matterial & 3.9 & 5.0 & Very Good \\
3 & Usefull & 3.9 & 5.0 & Very Good \\
& Average & 4.0 & 5.0 & Very Good \\
\hline
\end{tabular}

Results of validation by students indicated that the BUSAPAKSA was declared valid. All aspects were categorized as very appropriate with the average obtained score of 4.0 for which 5 was the maximum score.

The levels of appropriateness and quality of the product resulting from the development as learning medium were then measured. The level of appropriateness was measured through validation by experts in learning materials and media while the level of quality was measured through evaluation by psychologists, learning media experts, elementary school teachers. Results of validation by all validators indicated that the BUSAPAKSA was declared valid. Based on validators' assessment, BUSAPAKSA could fulfill the aspect of good learning media.

\section{Result of Boarder Trial}

Broader product testing was conducted on 360 students from twelve elementary schools in Brebes, Tegal, and Banyumas regency and Tegal city. The results of analysis are that the students' average gain score was classified into medium categories. The result of gain score could be seen in Table 6 .

Table 6

Gain score

\begin{tabular}{lllll}
\hline No & Aspect & Gain & Max Score & Category \\
\hline 1 & information regarding to the CSA prevention & 0.6 & 1.0 & Medium \\
2 & how the CSA perpetrators deceive the victims & 0.4 & 1.0 & Medium \\
3 & how to rescue the victims & 0.5 & 1.0 & Medium \\
Average & & 0.5 & 1.0 & Medium \\
\hline
\end{tabular}

The students' conceptual understanding was increased after conducting learning activities utilizing BUSAPAKSA. Media BUSAPAKSA introduced sexual education at elementary school through learning activities. BUSAPAKSA was one of good media utilized at elementary school. The students' gain score achievement was 0.43 which was classified into "moderate" category. The learning success indicator was due to the students' improving understanding through learning activities (Banyard, Williams, and Siegel, 2014). Learning processes were influenced by various variables, such as the quality of individuals, facilities, infrastructure, methods, media, and climate. One of those variables was media 
The students' conceptual understanding had already improved proven by the widely field tested product data. Students' understanding on information related to the CSA prevention was good already. The students' understanding was considered good as they might well absorb the information regarding to the CSA prevention, how the CSA perpetrators deceived the victims, and how to rescue the victims. The students' understanding on how to properly use internet was good, especially related to the school work completion, and communication. The students had understood their sexual organs which might not be touched by others. The students had understood the differences between male and female sexual characteristics. The students had understood that they might not be picked up by the unknown individuals (strangers) to go home after school. The students had understood that playing in a quiet place was dangerous. The students had understood that accepting goods from unknown individuals was the criminal perpetrators' ways to persuade the victims. The students had already understood that they might not be separated from the family members in public places. The students had already understood if there were unknown individuals and invite them to a certain place, they should loudly shout asking for a help. The students had already understood if an unknown adult touched their sexual organs or genitals, they should loudly shout or tell the situation to their parents.

BUSAPAKSA could improve conceptual understanding on CSA of elementary school students'. It was a kind of learning media which was a story book to improve the students' understanding on CSA. It contained cartoon pictures and stories. The books of Sulistyani, Jamzuri, and Rahardjo (2013) are printed media used by most elementary school students. Pocket book used is as one supporting instrument to deliver information about one-way learning materials and others to improve the students' potentials to become self-learners. Waluyanto (2005) states that comic books are visual communication media which may be utilized as educational instruments to effectively and efficiently deliver information. Bolton-Gary (2012) state that emotional elements (humor) and visualization (picture and text) may help the students improve their understanding on conceptual materials. Zain, Parmin, and Sumarni (2013) explain that comic-based modules may help the students understand the concepts and improve their learning outcomes.

\section{CONCLUSION}

The BUSAPAKSA is a set of learning media and comic as basis. A characteristic of BUSAPAKSA is well packaged in a story of friendship for elementary school students'. The BUSAPAKSA is quite appropriate and quite good to use as learning media, according to experts' and users' evaluation. According to field testing results, the BUSAPAKSA could improve students' conceptual understanding.

\section{RECOMMENDATION}

The Comic-based BUSAPAKSA may be utilized by the elementary school teachers to provide information in preventing children from sexual abuse. It is expected that the next research can develop BUSAPAKSA into a complete plot which focuses on the life of elementary school students in preventing themselves from CSA. Futhermore, it is recomended to design BUSAPAKSA in wider paper size so that conservation among characters in the comis can be read more easily. 


\section{ACKNOWLEDGMENT}

Special thanks to The Directorate General of Research and Community Service (Direktorat Riset dan Pengabdian kepada Masyarakat/DRPM), Directorate General of Research and Development, who have provided funding for this research. Head of Police Resort Brebes, Banyumas, Tegal dan Kota Tegal, principals and teachers, students, and validators who have provided assistance for this research.

\section{REFERENCES}

Al Haq, A.F., Raharjo, S.T., Wibowo, H. (2015). Kekerasan Seksual Pada Anak Di Indonesia. Journal Unpad. 2 (1), 31-36.

Arends, R. I. (2012). Learning to Teach, $7^{\text {th }}$. New York:McGraw Hill Company, Inc.

Azwar, S. (2012). Penyusunan skala pisikologi.Yogyakarta: Pustaka Pelajar.

Banyard, V. L., Williams, L. M., \& Siegel,J.A. (2004). Childhood sexual abuse: A gender perspective on context \& consequences. Child Maltreatment, 9 (3), 223-238.

Bolton-Gary, Cynthia. 2012. Connecting Through Comics: Expanding Opportunities for Teaching and Learning. US-China Education Review B4: 389-395.

Borg, W.R. \& Gall, M.D (1983). Educational Research: New York L: Logman.

Brown, Jon. 2013. The NSPCC Underwear Rule Campaign (Encouraging and enabling parents to talk with children to help keep them safe). Conference on preventing sexual abuse of children, Madrid, 10-11 December 2013.

Davis, RS (1997). Comics: a Multidimensional Teaching in Integrated-Skill Classes. Nagoyama University: Japan. (Online) Retrieved to February, 20, 2017 from http://www.esllab. com /research/ comics.htm

Dick, W., Carey, L., \& Carey, J. O. (2001). The systematic design of instruction (5rdeds.). New York: Longman.

Dube, S.R., Anda, R.F., Whitfield, C.L., Brown, D.W., Felitti, V.J., Dong, M., \& Giles, W.H. (2005). Long-term consequences of childhood sexual abuse by gender of victim. American Journal of Preventive Medicine, 28(5), 430-438.

Gagne, R. M (1970). Principle of Instruction Design. New York: Holt Rinehart and Winston.

Hake, R.R.(1998). Interactive-engagment versus traditional methods: a sixthousand student survey of mechanics test data for introductory physics courses. American Journal of Physics Research. 66 (1), 66-74.

Haryadi, T, Irawan, D.I.U. (2016). Penanaman nilai dan moral pada anak sekolah dasar Dengan Pendekatan Storytelling Melalui Media Komunikasi Visual. Jurnal Andhorupa, 2 (1):56-72.

Jatmikowati, T.E., Angin, R., Ernawati. (2005). Model Dan Materi Pendidikan Seks Anak Usia Dini Perspektif Gender Untuk Menghindarkan Sexual Abuse, Jurnal Cakrawala Pendidikan, 34(3), 434-448. 
Lazarini, Vitria. 2011. Kekerasan Dalam Rumah Tangga dan Pelecehan Seksual dalam Kehidupan Anak Usia Dini. Direktorat Jendral Pendidikan Anak Usia Dini Nonformal dan Informal: Kementerian Pendidikan Dan Kebudayaan.

Maharsi, Indria. (2010). Komik dunia kreatif tanpa batas. Yogyakarta: Kata Buku.

McCloud, Scout. 1001. Understanding Comic. Jakarta: Gramedia.

Mitchell, D. 2003. Children's Literature an Imitation to the Word. Michigan State University.

Noviana, Ivo. (2015). Kekerasan seksual terhadap anak: dampak dan penanganannya Child sexual abuse: impact and hendling. Jurnal Sosio Inform , 1 (1): 13-28.

Nurhidayati, Devi, Pratiwi, T.I.(2013). Pengembangan Media Video Untuk Meningkatkan Pemahaman Bahaya Seks Bebas Di Kalangan Remaja SMA Negeri 1 Soko Tuba. Jurnal Bimbingan Konseling UNESA, 1, (1):281-290.

Orange, L.M., \& Brodwin,M.G.(2005).Childhood sexual abuse: What rehabilitation counselors need to know. Journal of Rehabilitation, 71 (4), 5-12.

Paramastri, I dan Supriyati, Priyanto, M.A. (2010). Early Prevention toward Sexual Abuse on Children. Jurnal Psikologi, 21 (1): 1-12.

Paramastri, I., Prawitasari, J.E., Prabandari, Y.S., Ekowarni, E. (2011) Buklet sebagai media Pencegahan Kekerasan Seksual Pada Anak. Jurnal Kesehatan Masyarakat Nasional. 6(2):77-84.

Prabosiwi, R., Bahransyaf, D. 2015. Pedofilia Dan Kekerasan Seksual: Masalah Dan Perlindungan Terhadap Anak. Jurnal Sosio Informa, 1 (1): 29-40.

Pramono, R.B. (2014). Pendidikan Seksual Berbasis Budaya Sebagai Upaya Pencegahan Kekerasan Seksual Pada Anak Di Indonesia. Proseding Seminar Nasional Fakultas Pendidikan Psikologi Universitas Negeri Malang.

Rachmawati, Fauziyah. 2012. Pendidikan Seks Untuk Anak Autis. Elex Media Komputindo: Yogyakarta.

Santrock, J. W. (2008). Educational Psychology, $3^{\text {th }}$. New York:McGraw Hill Company, Inc.

Sulistyani, N.H.D., Jamzuri dan D.T. Raharjo. (2013). Perbedaan Hasil Belajar Siswa Antara Menggunakan Media Pocket Book dan Tanpa Pocket Book Pada Materi Kinematika Gerak Melingkar Kelas X. Jurnal Materi dan Pembelajaran Fisika. 1 (1):164-173.

Waluyanto, D.W. 2005. Komik Sebagai Media Komunikasi Visual Pembelajaran. Journal NIRMANA, 7 (1): 45-55.

Zain, N. H., Parmin, Sumarni, W. (2013). Pengembangan Komik Bahan Ajar IPA Terpadu Kelas VIII SMP Pada Tema Sistem Pencernaan Manunisa dan Hubungannya Dengan Kesehatan, Unnes Science Education Journal, 2 (1): 217-222. 